\title{
The Impact of Humans on Strata Formation Along Mediterranean Margins
}

BY CAMINO LIQUETE, MIQUEL CANALS, PEDRO ARNAU, ROGER URGELES, AND XAVIER DURRIEU DE MADRON

\section{RIVERS FLOWING INTO THE MEDITERRANEAN: A SEA OF CONTRASTS}

The Mediterranean and Black Seas are micro-tidal and less than $3 \times 10^{6} \mathrm{~km}^{2}$ and $500 \mathrm{~km}^{2}$ in area, respectively. The latter is connected to the Mediterranean Sea by the narrow Bosphorus-Dardanelles Strait. Both seas have an important continental influence because they are semi-enclosed basins with relatively large riverine sediment inputs. The most important fluvial systems flowing into the Mediterranean and Black Seas are the Ebro, Rhône, Po, Danube, and Nile Rivers (Figure 1). They represent the largest sediment contribution to Mediterranean margins.

The mean monthly discharge regime is clearly different among the European rivers. Maximum discharge occurs normally during the spring, with the Danube having the greatest discharge of the five systems (Table 1 and Figure 2). Because the Nile River is influenced by the El Niño-Southern Oscillation and the monsoons, its maximum discharge occurs in July; however, the Nile River is presently so regulated that its discharge is nearly constant (Figure 2). The Nile is characterized by low runoff, at least one order of magnitude smaller than the other Mediterranean and Black Sea rivers (Table 1). The Rhône River feeds the largest delta relative to its basin area, and the Po River shows the highest runoff.

Thus, in spite of its relatively small surface area, Mediterranean watersheds offer important contrasts. Annual rainfall varies from more than $1,500 \mathrm{~mm}$ on the European mountain ranges to less than $100 \mathrm{~mm}$ inland northern Africa and western Asia. In addition, there are important dimensional disparities among the fluvial systems. The hundreds of smaller river catchments that surround the Mediterranean provide a major sediment contribution through frequent flood events. 


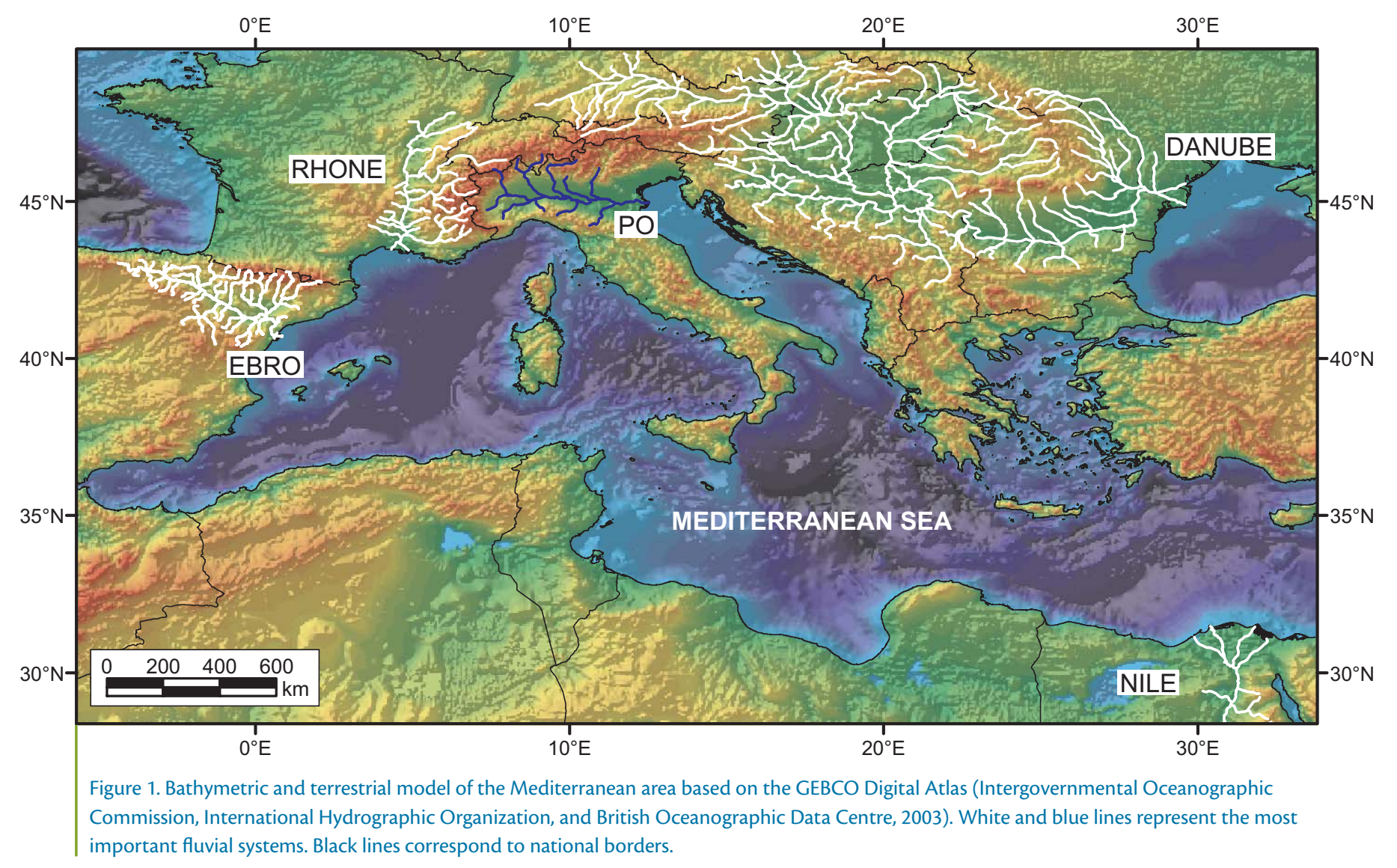

One of the most significant factors controlling sediment discharge in the Mediterranean region over the last few millennia is the development of civi-

Camino Liquete is PhD student, GRC Geociències Marines, Universitat de Barcelona, Spain. Miquel Canals (miquelcanals@ub. edu) is Professor, GRC Geociències Marines, Universitat de Barcelona, Spain. Pedro Arnau is Research Assistant, GRC Geociencies Marines, Universitat de Barcelona, Spain. Roger Urgeles is Research Assistant, GRC Geociències Marines, Universitat de Barcelona, Spain. Xavier Durrieu de Madron is Professor, CEFREM, Université de PerpignanCNRS, Perpignan, France. lization. Anthropogenic influence has increased during the last centuries and, especially, during the twentieth century. During the Holocene, numerous Mediterranean river systems formed deltas up to $40 \mathrm{~m}$ thick (Poulos and Collins, 2002), while during the twentieth century most of them have experienced rapid erosion as humans have impacted sediment supply (McManus, 2002).

Human pressures around the Mediterranean continue to increase through population expansion and high levels of tourism. Human activities impact the marginal seabed both directly and indirectly.

\section{THE HUMAN IMPACT}

\section{Indirect Impacts}

\section{Global Change and Mediterranean Sensitivity}

In spite of the controversy about how global climate is changing, it is broadly accepted that human practices have influenced the world climatic patterns- 70 percent of the present-day sources of atmospheric methane have an anthropogenic origin (Ruddiman, 2001). Rapid alterations in oceanic and atmospheric cycles have occurred during the last 150 years, which have had an impact on sensitive systems such as the Mediterranean. Land-sea interactions 
are further exaggerated in the Mediterranean Sea due to the relatively small water exchange with the Atlantic, the role of evaporation on its thermohaline circulation, and the fragility of its extremely highly diverse ecosystems.

The major impact of climatic change on strata (sea bed) formation in the Mediterranean comes through changes to the fluvial system. Although global warming can intensify the global hydrological cycle and increase the risk of floods (Milly et al., 2002; Labat et al., 2004), to date the local hydroclimatic patterns do not show such a trend (Arnau et al., 2004; Ludwig et al., 2004). In general, most Mediterranean rivers show either declining runoff or no relevant trends (Walling and Fang, 2003); both trends are in agreement with the general tendency towards aridity recorded in the western Mediterranean since 5,400 before present (Goy et al., 2002). Nevertheless, Labat et al. (2004) point to a positive correlation between global annual temperature and runoff at the global scale, even when both increasing and decreasing trends have been identified at the regional scale.

Another significant indirect effect of human activity in the Mediterranean Sea is biological invasions, which have occurred since the opening of inter-ocean maritime routes five centuries ago. One of the most important human-induced biological invasions in the Mediterranean coastal waters is the tropical algae Caulerpa taxifolia. It is thought that these algae were introduced into the Mediterranean through a release from the Aquarium of Monaco during the 1980s. Since then, fast spread of Caulerpa spp. has been observed along western Medi-

\begin{tabular}{|c|c|c|c|c|}
\hline & $\begin{array}{l}\text { Mean discharge } \\
\text { near the river } \\
\text { mouth }\left(\mathrm{m}^{3} / \mathrm{sec}\right)\end{array}$ & $\begin{array}{l}\text { River length } \\
(\mathrm{km})\end{array}$ & $\begin{array}{l}\text { Basin area } \\
\left(\mathrm{km}^{2}\right)\end{array}$ & $\begin{array}{l}\text { Runoff } \\
(\mathrm{mm} / \mathrm{yr})\end{array}$ \\
\hline Danube & 6,488 & 2,850 & 817,000 & 254.0 \\
\hline Rhône & 1,693 & 812 & 95,500 & 557.6 \\
\hline Po & 1,515 & 652 & 71,057 & 681.3 \\
\hline Ebro & 483 & 982 & 85,708 & 464.7 \\
\hline Nile & 1,251 & 6,695 & $3,035,000$ & 13.0 \\
\hline
\end{tabular}

Table 1. Main characteristics of the five largest river systems flowing into the Mediterranean and Black Seas (see Figure 1).
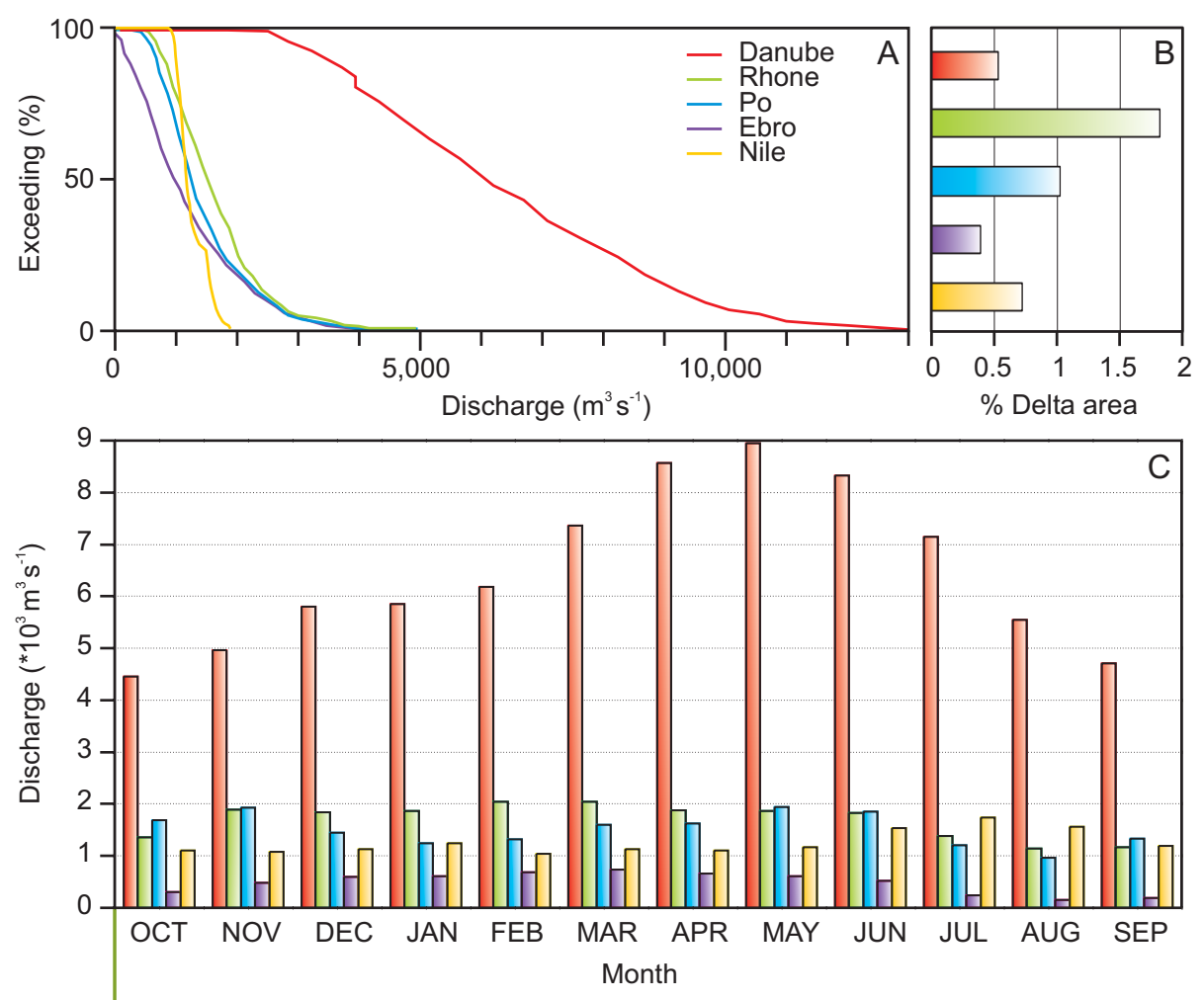

Figure 2. Comparative analysis of the Danube, Rhône, Po, Ebro, and Nile Rivers. Water-discharge values are from gauging stations nearest to each river mouth (Ceatal Izmail, Beaucaire, Pontelagoscuro, Tortosa, and el Ekhsase, respectively). (a) Flow duration curves of the five systems (i.e., time probability [vertical axis] that a given flow [horizontal axis] will be equaled or exceeded). The Nile River shows an extremely constant discharge. (b) Percentage of each delta area relative to its corresponding basin area, showing the Rhône Delta to be the most significant. (c) Mean monthly discharge of the five rivers. Danube discharge is noticeably greater than the rest, and the European rivers show a clearly different discharge regime from that of the Nile. 
terranean coasts (Occhipinti-Ambrogi and Savini, 2003). Caulerpa spp. are replacing the endemic Posidonia oceanica angiosperm that significantly promote sediment stability and accretion. Sediment resuspension in a littoral zone covered by $P$. oceanica is three times smaller than comparatively unvegetated sea bottoms (Gacia and Duarte, 2001). Therefore, $P$. oceanica extinction through competition with Caulerpa spp. may increase erosion appreciably in the coastal zone.

\section{Changes in Vegetation Cover and Land Use}

Until 2,000 years ago, the primary change for cultivated land use in the Mediterranean watershed was solely governed by climate. In the early Holocene, agriculture appeared along the north and northeast coasts of the eastern Mediterranean basin and, in the next millennia, it extended slowly inland (Figure 3). About 7,000 years ago, most of the Mediterranean coastal area was already developed for agriculture (Figure 3 ).

The largest human modifications on vegetation cover and consequent sediment transport to the ocean are from deforestation, which in the Mediterranean region dates from two millennia before present. As a result, in addition to the effect on soil erosion, a regional change of the hydrological cycle that alarmingly promotes desertification is observed. Subsequent land degradation enhances the release of sedimentary particles that are later transported by rivers, even when land protection practices are implemented (e.g., land terracing in the Mediterra- nean is as old as 2,500 years).

At a shorter time scale, since 1990, it is globally estimated that six million hectares of productive land have been lost per year due to land degradation, although recent trends indicate that there has been an increase of Europe's forest cover, in both area and volume, over the past 30 years (United Nations Economic Commission for Europe and the Food and Agriculture Organization, 2000). Some areas around the Mediterranean basin, such as southern Spain, are presently undergoing important erosion problems caused by the combination of soil composition, steep slopes, insufficient vegetation cover, climate change, and inappropriate agricultural practices (Consejeria de Medio Ambiente, 1997).

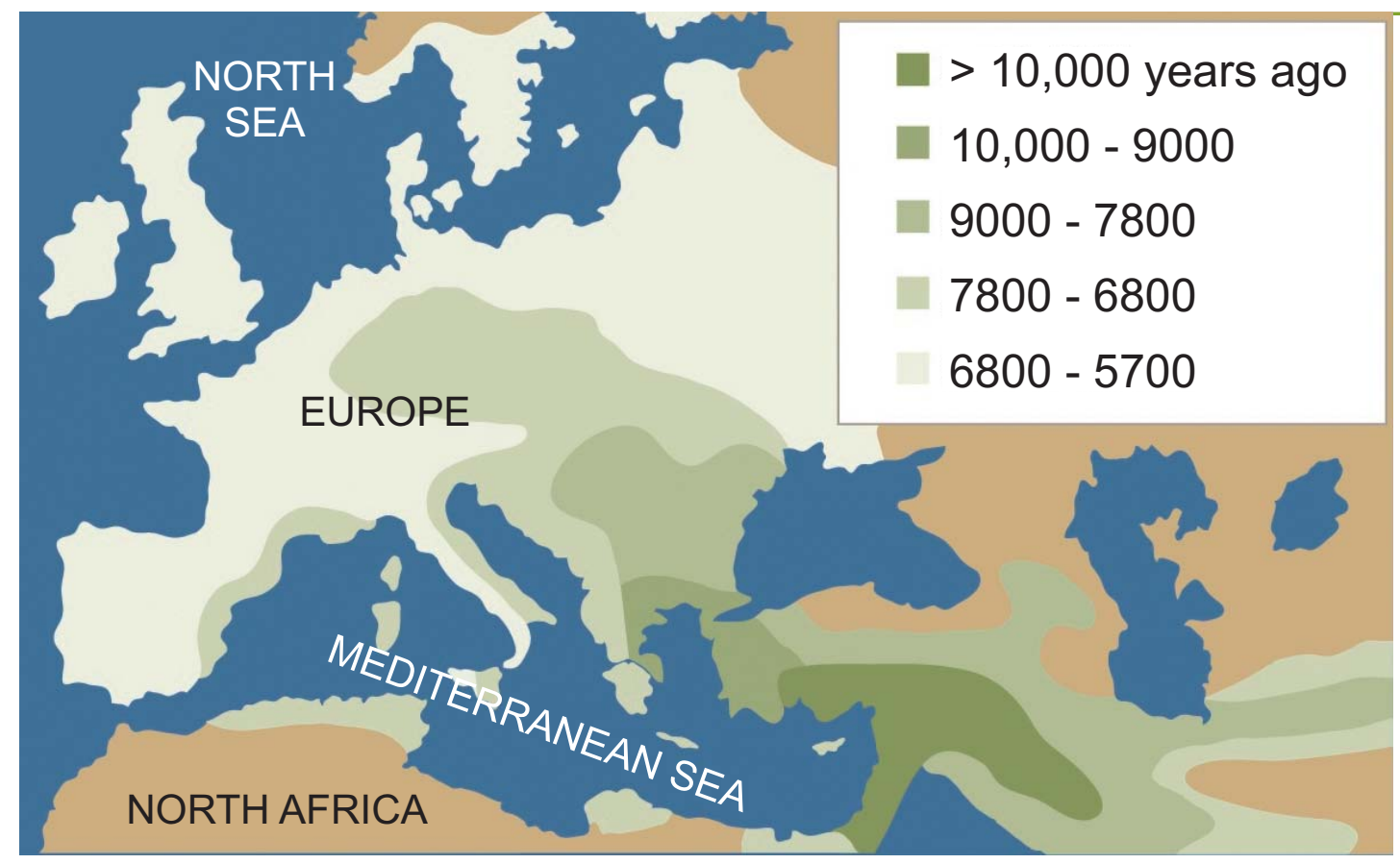

Figure 3. Spread of agriculture around the Mediterranean Sea throughout the Holocene (after Ruddiman, 2001). Ten thousand years ago, early agriculture appeared at the north and northeast coasts of the eastern Mediterranean basin; however, about 7,000 years ago, most of the Mediterranean coastal area was already affected by crops. 


\section{Direct Impacts}

\section{Damming}

River regulation is a significant issue in the Mediterranean watershed, as illustrated in Figure 4. The recent expansion of dams and reservoirs devoted to hydroelectrical power production, irrigation, and flood control has led to a dramatic cut-off of rivers' solid discharge. One of the most impressive cases around the Mediterranean basin occurs along the Nile River course, where the Aswan Dam and intensive irrigation have achieved an entrapment of more than 98 percent of the sediment load. A similar situation takes place in the Ebro watershed, where more than 187 dams regulate 96 percent of the basin area, 57 percent of the mean annual runoff (Batalla et al., 2004), and 99 percent of the solid discharge (Ibañez et al., 1996).

In fact, according to Vorosmarty et al. (2003), European regulated river basins display the highest mean sediment retention in large artificial impoundments (50 percent) compared to the 25 to 30 percent global mean. Furthermore, it has

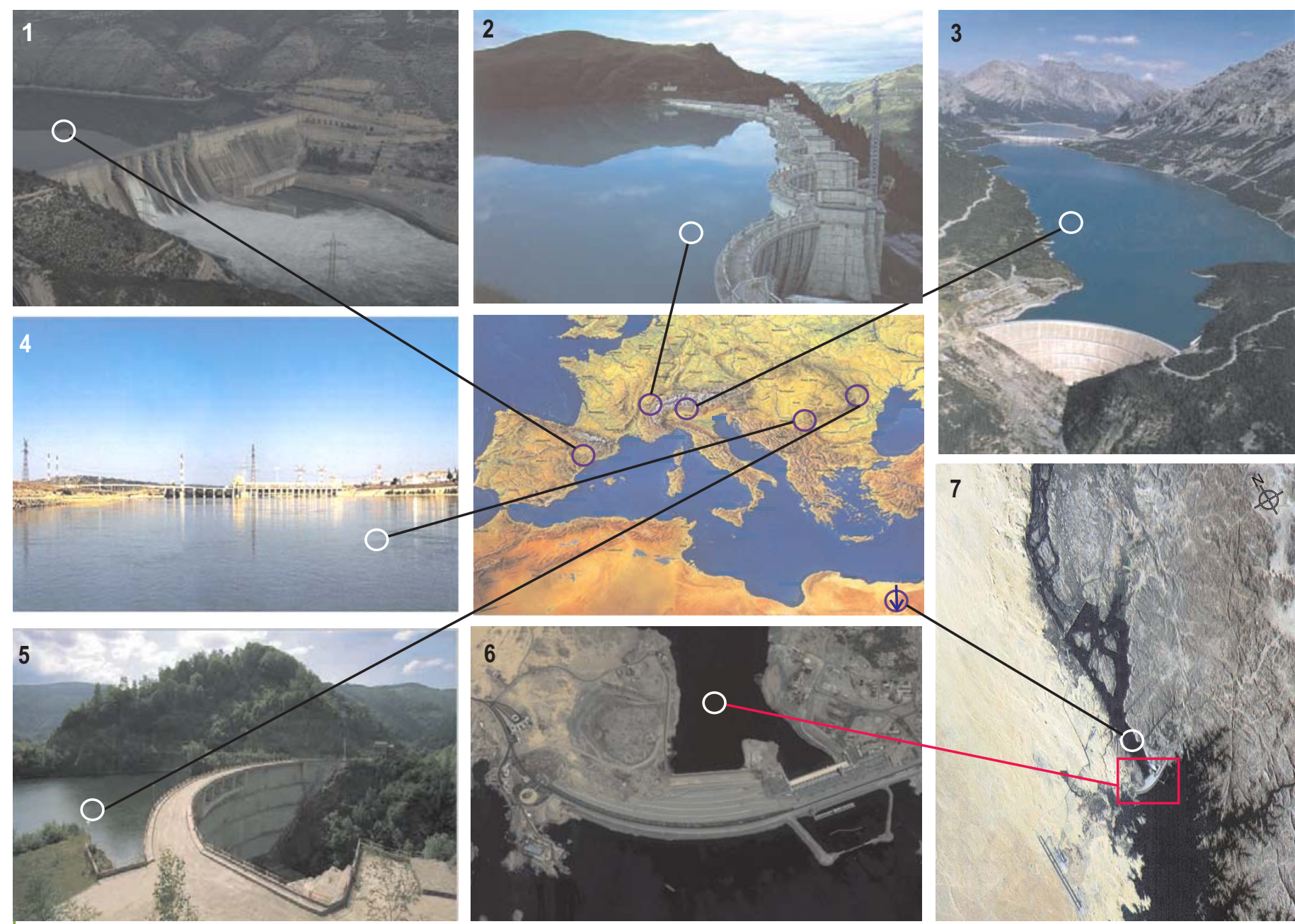

Figure 4. Seven large dams and reservoirs in the major Mediterranean rivers: (1) Mequinenza Dam on the Ebro (1966; 1,534 x 10 $\left.\mathrm{m}^{3}\right)$ ), (2) La Girotte Dam on the Dorinet Stream, tributary of the Rhône River (1944-49; $\left.50 \times 10^{6} \mathrm{~m}^{3}\right)$, (3) di Cancano Dam in the Alpine Fraele Valley (1953-56; 123 x 106 $\left.\mathrm{m}^{3}\right)$, (4) Iron Gates Dam at mid course of the Danube River $\left(1972 ; 600 \times 10^{6} \mathrm{~m}^{3}\right)$, (5) Tau Dam on the Seber Stream, tributary of the Danube River within the Carpathian region $\left(1984 ; 21 \times 10^{6} \mathrm{~m}^{3}\right),(6)$ Aswan High Dam in the Nile River low course (1960-68; $\left.17 \times 10^{13} \mathrm{~m}^{3}\right)$, and (7) Satellite view of the Aswan High Dam and the artificial Lake Nasser. 
been estimated that numerous Spanish reservoirs show a trap efficiency of more than 90 percent (Confederacion Hidrografica del Guadalquivir, 1994). This retention of particles in the reservoirs obviously leads to intense sediment starvation along the seaward margin.

During the last century, coastal retreat linked to a reduction in the sediment load supplied by the Ebro, Po, and Nile Rivers exceeded annual rates of $10 \mathrm{~m}$ (McManus, 2002). The sediment load carried by the Danube system has decreased 41 percent between midnineteenth century and the end of the twentieth century, even though its liquid discharge is known to have increased 14 percent during the same time period (Giosan et al., 1999).

For the Spanish Mediterranean watersheds (Figure 5), the area of the drainage basins filtered by reservoirs went up from nearly 3 percent (less than 5,000 $\mathrm{km}^{2}$ ) in 1908 to 12 percent in 1940. In 1960 more than $40,000 \mathrm{~km}^{2}$ (about 22 percent of the total basin area) were located behind dams, and in 1972 this area reached 63 percent and included most of the Ebro watershed. However, some regions such as the southern basins had no noteworthy impoundments until the 1970s. By 1990, 129,000 km² of the Spanish Mediterranean river systems (equivalent to 71 percent) were regulated.

\section{Seashore Actions}

Coastal infrastructures, usually lacking an adequate environmental assessment, intersect littoral drift causing important erosive problems and sedimentary imbalances. To avoid the ensuing financial losses, beach refilling is a common practice in the touristic Mediterranean seashores. In some countries, such as Greece, this kind of beach nourishment is not common. Nevertheless, in other areas it is a frequently adopted solution. For instance, Italy started filling beaches in 1962 and since then $12 \times 10^{6} \mathrm{~m}^{3}$ of sediments have been used; however, the major intervention has taken place in Spain-since $1983110 \times 10^{6} \mathrm{~m}^{3}$ have been added to the seashore, predominantly in the Mediterranean region.

The Almassora coast, located south of the Ebro delta, is one of the countless Mediterranean littoral systems that have undergone a progressive degradation during the twentieth century (Figure 6). Southward littoral drift along this coast is interrupted by the Port of Castellon and the Serrallo industrial estate. The result has been dramatic coastal erosion on Almassora beaches since 1947. Local management actions carried out during the last thirty years—such as beach fill and dike construction-managed to prevent erosion and even to double beach area. However, seaside quality has considerably decreased and the nearby Mijares delta is now experiencing noteworthy erosion.

Figure 5. Damming history of the Spanish Mediterranean watersheds during the twentieth century. Unregulated basin area is green colored while regulated area is shown in red. The Ebro watershed is bordered by a brown line. Regulated area went up from nearly 3 percent of the total basin area in 1908 to 12 percent in 1940. In 1960, about 22 percent of the watersheds were located behind dams; in 1972, this rate reached 63 percent and included most of the Ebro basin. Finally, in 1990, 71 percent of the Spanish Mediterranean river systems (up to $129,000 \mathrm{~km}^{2}$ ) were regulated.
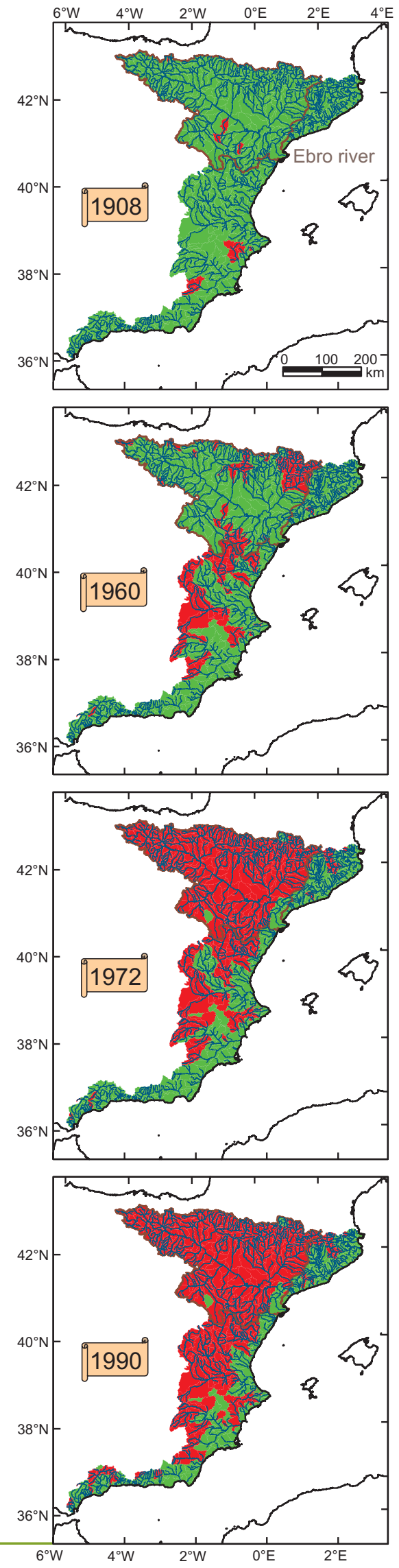

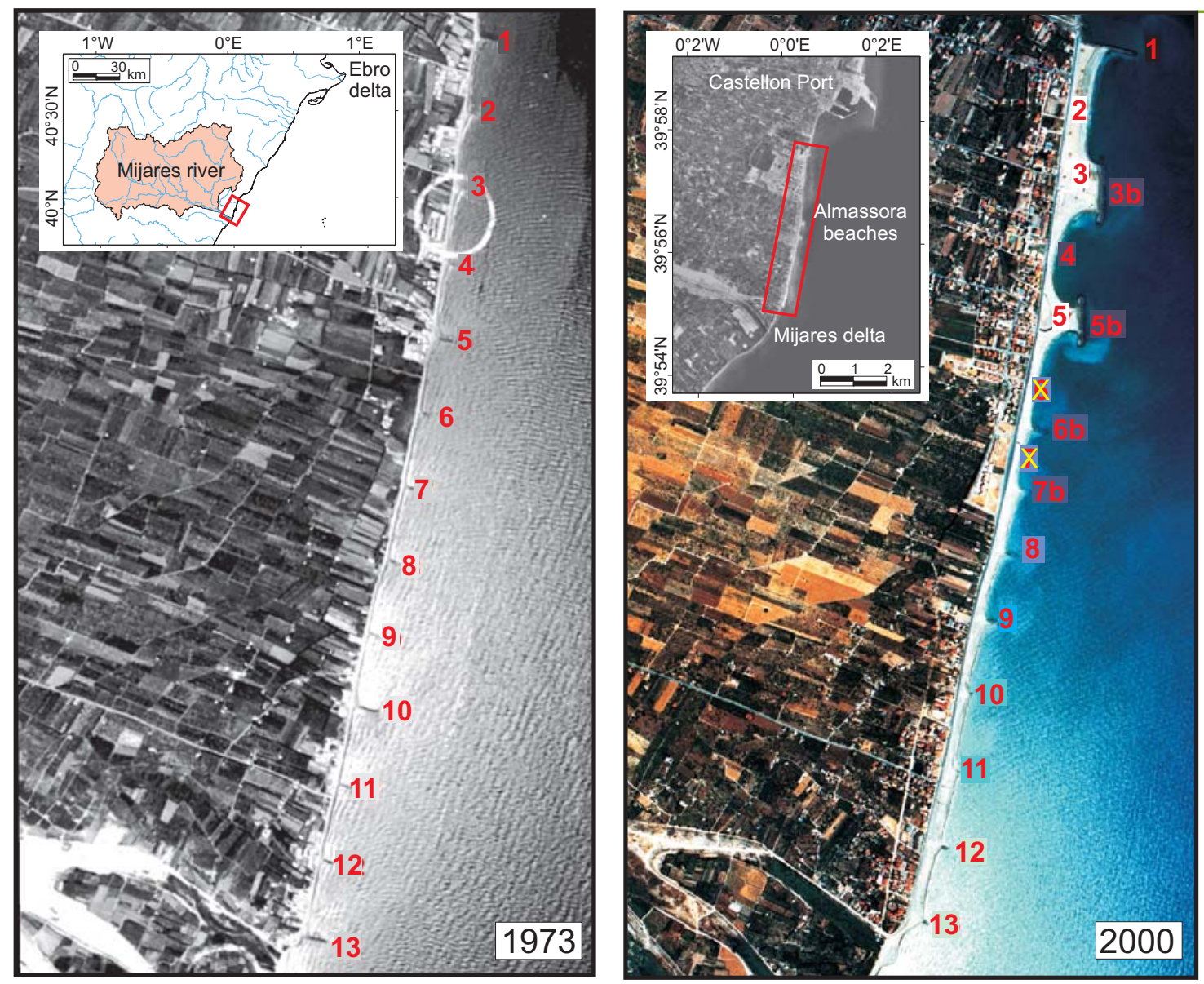

Figure 6. Almassora coast evolution through the last 30 years. At the beginning of the 1970s, beaches were almost depleted due to the littoral drift cut-off caused by the Port of Castellon and the Serrallo industrial estate. However, later corrective actions, such as beach infilling and dike construction, managed to double beach area to the detriment of the nearby Mijares delta. Red numbers denote the constructed dikes while yellow crosses and letters point to their subsequent changes.

\section{Trawling}

Mobile demersal fishing gear (trawls, dredges, gillnets) generate an environmental impact in terms of substrate plowing and sediment resuspension. Otter trawl is the most common bottom gear used by commercial fishermen in the Mediterranean. The most visible impacts are (1) the furrows imprinted in the seabed (by the doors of the trawls), which may remain for years (until bottom currents smooth them or sedimentation cover them) (Figure 7a), and (2) the increase in water turbidity in muddy areas (Palanques et al., 2001). A recent work by Durrieu de Madron et al. (in press) indicates that only a small fraction of remobilized sediment rises a few meters above the seabed. The largest portion of resuspended sediment settles during the first hour after the passage of the trawl, and the load remaining in suspension supplies the bottom nepheloid layer (Figure 7b). Thus, trawling must be considered a relevant factor in seabed modification along Mediterranean margins, particularly in countries where bottom-trawling activity is important, such as Spain, France, Italy, and Greece. Anchoring activities can also deplete the seagrass cover of the Mediterranean margins (e.g., the aforementioned P. oceanica meadows), promoting even more sediment remobilization.

\section{CONCLUSIONS}

The Mediterranean basin is a relatively sensitive environment where anthropogenic influence dates from millennia ago, and where its regional climate is more continental in origin than marine. There are important contrasts within the Mediterranean watersheds and in the continental supply of sediment.

During the twentieth century, hu- 
a

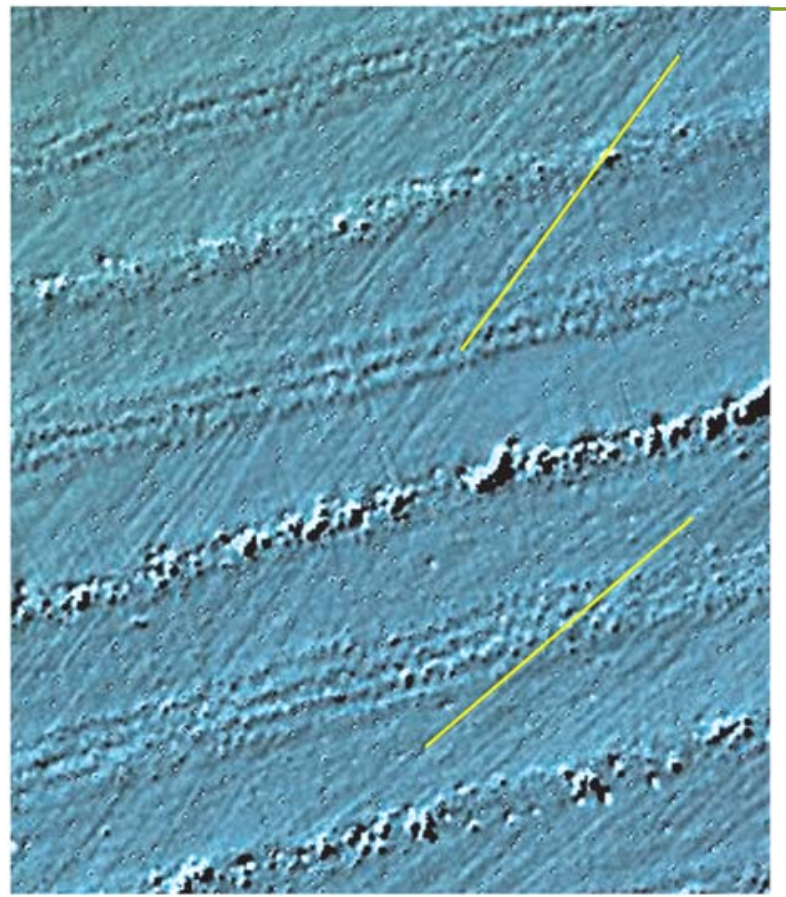

Figure 7. (a) Sets of trawl marks observed on a

shaded relief image built from an EM3000 dual multibeam echosounder on an unspecified part of the Spanish continental shelf. Image is $700 \times 800 \mathrm{~m}$ with $2 \mathrm{~m}$ pixel size. Yellow lines point to the directions of some of those marks. (b) Suspended sediment concentration distribution of a plume segment at various times after its generation by a bottom trawl (after Durrieu de Madron et al., in press). Bottom scales indicate the elapsed time since the passage of the trawl and the distance covered by the ship transecting the turbid plume. b

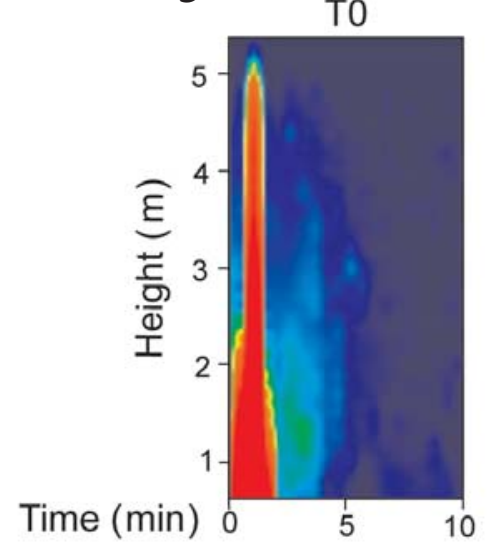

Distance $(m) 10 \quad 110 \quad 210 \quad 310$

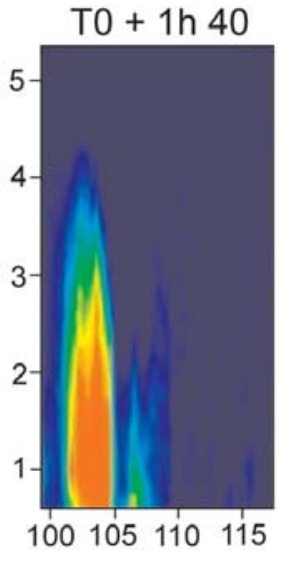

180020002200
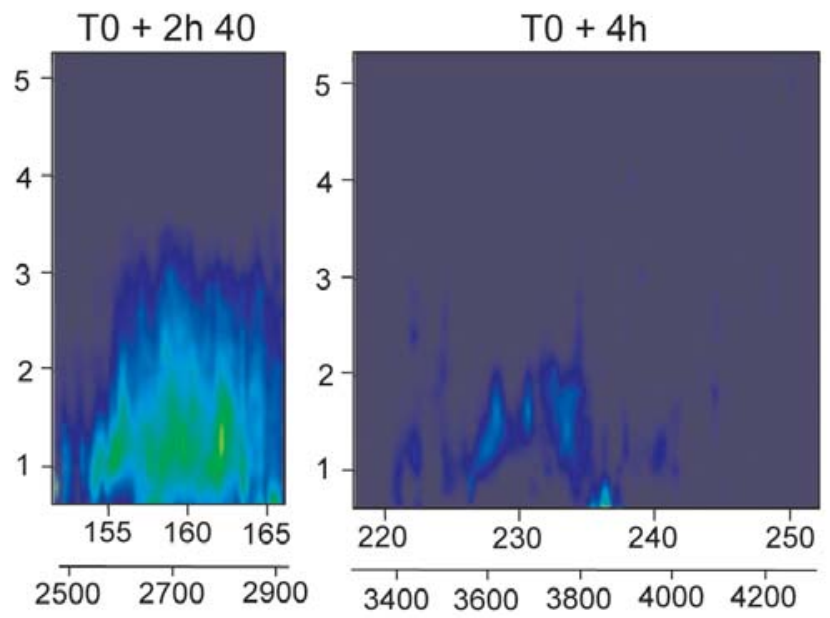
man activities have altered marine strata formation by modifying natural environmental factors related to regional sedimentary routes (indirect impacts) or by openly interrupting local sedimentary processes (direct impacts).

The most relevant indirect impacts include (1) the influence of global climate change on the supply of sediment by rivers, and (2) the modification of sediment yield due to land use changes and desertification.

Some significant anthropogenic direct impacts on strata formation include (1) river regulation and diversion projects that interrupt natural sediment loads, (2) coastal-zone activities, such as infrastructures that are able to interfere with natural sediment transport and accumulation and, hence, cause important erosion problems, or massive beach-fill efforts that change littoral systems, and (3) trawling activities that stir and resuspend the seabed.

\section{ACKNOWLEDGEMENTS}

This work was funded by the Concerted Action "European Coordination on Mediterranean and Black Sea Prodeltas" ("Eurodelta” contract EVK3-CT-200220001), the Spanish RTD project "Prodelta” (contract REN2002-02323), and the European "Eurostrataform” project (contract EVK3-CT-2002-00079). C. Liquete benefited from a FPI fellowship and R. Urgeles from a Ramon y Cajal fellowship, both awarded by the Spanish Ministry for Science and Technology. 菂

\section{REFERENCES}

Arnau, P., C. Liquete, and M. Canals. 2004. River mouth plume events and their dispersal in the Northwestern Mediterranean Sea. Oceanography 17(3):22-31.

Batalla, R.J., C.M. Gomez, and G.M. Kondolf. 2004. Reservoir-induced hydrological changes in the Ebro River basin (NE Spain). Journal of Hydrology 290(1-2):117-136.

Confederacion Hidrografica del Guadalquivir. 1994. Redaccion de la Propuesta del Plan Hidrologico del Guadalete - Barbate, 49 pp.

Consejeria de Medio Ambiente (Junta de Andalucia). 1997. La problematica asociada al suelo y al paisaje. Pp. 81-99 in Plan Andaluz de Medio Ambiente 1997-2002.

Durrieu de Madron X., B. Ferre, G. Le Corre, C. Grenz, P. Conan, M. Pujo-Pay, O. Bodiot, and R. Buscai. In press. Trawling-induced resuspension and dispersal of muddy sediments and dissolved elements. Continental Shelf Research.

Gacia, E., and C.M. Duarte. 2001. Sediment retention by a Mediterranean Posidonia oceanica meadow: The balance between deposition and resuspension. Estuarine, Coastal, and Shelf Science 52:505-514.

Giosan, L., H. Bokuniewicz, N. Panin, and J. Postolache. 1999. Longshore sediment transport pattern along the Romanian Danube delta coast. Journal of Coastal Research 15:859-871.

Goy, J.L., C. Zazo, and C.J. Dabrio. 2002. A beachridge progradation complex reflecting periodical sea-level and climate variability during the Holocene (Gulf of Almeria, Western Mediterranean). Geomorphology 50:251-268.

Ibañez, C., N. Prat, and A. Canicio. 1996. Changes in the hydrology and sediment transport produced by large dams on the lower Ebro river and its estuary. Regulated Rivers 12:51-62.

Intergovernmental Oceanographic Commission, International Hydrographic Organization, and British Oceanographic Data Centre (IOC, IHO, and BODC). 2003. Centenary Edition of the GEBCO Digital Atlas, published on CD-ROM on behalf of the Intergovernmental Oceanographic Commission and the International Hydrographic Organization as part of the General Bathymetric Chart of the Oceans, British Oceanographic Data Centre, Liverpool.

Labat D., Y. Godderis, J.L. Probst, and J.L. Guyot. 2004. Evidence for global runoff increase related to climate warming. Advances in Water Resources 27:631-642.
Ludwig W., P. Serrat, L. Cesmat, and J. Garcia-Esteves. 2004. Evaluating the impact of the recent temperature increase on the hydrology of the Tet River (Southern France). Journal of Hydrology 289:204-221.

McManus, J. 2002. Deltaic responses to changes in river regimes. Marine Chemistry 79:155-170.

Milly, P.C.D., R.T. Wetherhald, K.A. Dunne, and T.L. Delworth. 2002. Increasing risk of great foods in a changing climate. Nature 42(15):514517.

Occhipinti-Ambrogi, A., and D. Savini. 2003. Biological invasions as a component of global change in stressed marine ecosystems. Marine Pollution Bulletin 46(5):542-551.

Palanques, A., J. Guillen, and P. Puig. 2001. Impact of bottom trawling on water turbidity and muddy sediment of an unfished continental shelf. Limnology and Oceanography 46(5): 1,100-1,110.

Poulos, S.E., and M.B. Collins. 2002. Fluviatile sediment fluxes to the Mediterranean Sea: A quantitative approach and the influence of dams. Pp. 227-245 in Sediment Flux to Basins: Causes, Controls and Consequences. S. Jones and L.E. Frostick, eds. GSL Special Publication 191. Geological Society of London.

Ruddiman, W.F. 2001. Earth's Climate: Past and Future. W.H. Freeman \& Sons, New York, 465 pp.

United Nations Economic Commission for Europe and the Food and Agriculture Organization (UNECE/FAO). 2000. Forest resources of Europe, CIS, North America, Australia, Japan and New Zealand: Contribution to the global Forest Resources Assessment 2000. Geneva Timber and Forest Study Paper 17. New York and Geneva, 445 pp.

Vorosmarty, C.J., M. Meybeck, B. Fekete, K. Sharma, P. Green, and J. Syvitski. 2003. Anthropogenic sediment retention: Major global impact from registered river impoundments. Global and Planetary Change 39:169-190.

Walling, D.E., and D. Fang. 2003. Recent trends in the suspended sediment loads of the world's rivers. Global and Planetary Change 39:111-126. 